\title{
Quantitative Ethobotany of Gnetum africanum Welw. (Gnetaceae) in Massoumboum, Littoral Region of Cameroon
}

\author{
Jean Lagarde Betti ${ }^{1,2}$, Pascal Eric Billong Fils ${ }^{1}$, Prisca Toffon ${ }^{1}$, Eric Wété ${ }^{1}$, Jules Romain Ngueguim ${ }^{3}$, Oumar \\ Farick Njimbam $^{1} \&$ Stéphanie Tientcheu Womeni ${ }^{1,2}$ \\ ${ }^{1}$ Department of Plant Biology, Faculty of Sciences, University of Douala, BP 24157 Douala, Cameroon \\ ${ }^{2}$ Institute of Agricultural Research for Development (IRAD), Liaison Agency, Douala, Cameroon \\ ${ }^{3}$ Higher Teacher Training College of Bertoua, Cameroon \\ Correspondence: Jean Lagarde Betti, Department of Plant Biology, Faculty of Sciences, University of Douala, \\ Cameroon, BP 24157 Douala, Cameroon. Tel: 237-677-303-272. E-mail: lagardeprunus@gmail.com
}

Received: February 21, 2019

doi:10.5539/jps.v8n2p19
Accepted: March 15, 2019 Online Published: June 16, 2019

URL: https://doi.org/10.5539/jps.v8n2p19

\begin{abstract}
Gnetum africanum Welw. is a plant specie of Central and West Africa, a Non Timber Forest Product (NTFP) with high nutritional, medicinal and economic value. In Cameroon, its leaves are recognized by the forestry administration as a special product. Strong demand combined with destructive harvesting techniques has resulted in its rarity in its distribution area. The objective of this work is to characterize the harvesting and trade of $G$. africanaum, and to assess its abundance (density and structure) in order to appreciate the economic value of the Lehman agroforest system (ALM) based in Massoumboum, a village located at $30 \mathrm{Km}$ of Douala town, the economical capital of Cameroon. An ethnobotanical survey was conducted among harvesters and sellers of $G$. africanum in the ALM and in adjacent markets. An inventory of G. africanum stems and leaves was carried out at an overall sampling rate of $9.52 \%$. The study revealed that, harvesting of G. africanum is freely done by women, youngers and elders. They start their activity early in the morning and convey their products to markets located in the periphery and inside the city of Douala. The price of the gramme is too high in the periphery than in the city, averaging 0.58 CFA franc. This price is high in the dry season due to the scarcity of other agricultural vegetables. The inventories conducted revealed densities of 6191 stems/ha and 119548 leaves/ha, with the high density of leaves obtained in less perturbed plots. The combination of field data (forest inventories) with those obtained in the markets (trade data), what we call «quantitative ethnobotany », allowed us to appreciate the temporal economic value (EV) of the ALM. This EV ranges from 500000 - 700000 CFA franc, for an average value of $37059.9 \mathrm{CFA}$ franc /ha. If well managed, G. africanum can contribute not only to the economy of the women-harvesters, but also to the economy of the ALM. The glaring development challenge of the background of what precedes is the development of non-detriment findings (NDF) for G. africanum in Cameroon. These consist of setting tools which aims to sustain the resource and trade such as the delimitation of Gnetum Allocation Units (GAU), as well as the development and implementation of simple management plans (SMPs).
\end{abstract}

Keywords: NTFP, Gnetum africanum, Lehman agroforest system of Massoumboumm (ALM), quantitative ethnobotany, economic value, non-detriment findings (NDF).

\section{Introduction}

Forests provide goods and services which are important for more than 1.2 billions of people all over the world. In Africa, the life of more than $80 \%$ of poor people depends on natural resources, composed mainly of non timber forest products (NTFP). The contribution of NTFP in the national economy is often less appreciated due to the lack of statistical data (Awono et al., 2013; Betti, 2007). Gnetum africanum and Gnetum buchholzianum are two NTFP of the Gnetaceae family group, found in Cameroon. The first and the most appreciated by people is G. africanum that is largely harvested in the regions of Centre (Obala, Sa'a, Bot makak, Boumnyébel, Awaii) and South (Meyomessala). The second specie, G. buchholzianum is less appreciated and is mostly found at Souza in the Littoral region and at Takamanda forest reserve in the South west region (Mbolo, 2002).

G. africanum and G. buchholzianum are lianas, which leaves are used by several peoples of the Central Africa. In Cameroon, the name of the plant varies according to the region. Hence, the plant is called Kok by the Beti; 
Eru by people from the North West and South West, Hikok for the Bassa ; Ikiokio for the Yambassa ; Kiwa for the Bafia ; Koko at Batouri, Bissom at Yokadouma ; Ekoke among the Douala ; Kege for the Bankon ; Ekok for the Bakaka ; and Mbiare in households and publics areas found in cities/towns (FAO, 2002). G. africanum and G. buchholzianum are mostly used as medicinal and food plants. Ethnobotanical inquiries conducted in Kinshasa revealed that about $80 \%$ of the population eat leaves of G. africanum at least once per week (Toirambe, 2002).

In Cameroon, G. africanum leaves are exported from the Yaoundé Nsimalen airport and the Idenau port. Products are largely destined to America, Europe, and Nigeria (Mbolo, 2002). In 1998, Cameroon exported a total of 50 tons of G. africanum leaves to Europe (Tabuna, 1999). About 4180 tons of G. africanum leaves is harvested each year in the Centre, Littoral and South West regions of Cameroon. The trade is evaluated at 13.8 millions of American dollars per year in the South West region of Cameroon (Tabuna, 1999). The high demand coupled with the bad harvesting technics used have conducted to the scarcity of the resource in its range areas. This leaded the International Union for the Nature Conservation (IUCN) to insert G. africanum in the red list. In Cameroon, G. africanum is classified together with Prunus africana and other forest products, by the forest administration as a special product of particular interest. But several difficulties link mostly to the less knowledge of the resource do not allow to settle suitable schemes for sustaining the trade. Except for $P$. africana (Betti et al., 2011), no management inventories have been conducted for other special product of particular interest in Cameroon.

This paper aims to characterize the harvesting and trade of G. africanaum, and to assess its abundance (density and structure) in order to appreciate the economic value (EV) of the Lehman agroforest system at Massoumboum (ALM), Littoral region of Cameroon. The specific objectives are: (1) to characterize the harvesting and the trade of G. africanum, (2) to assess the abundance and structural characteristics of $G$. africanum in the ALM, and (3) based on results obtained in (1) and (2), appreciate the economic value of the ALM.

\section{Materials and Methods}

\subsection{Study Site}

Massoumboum is a village situated in the Council of Yabassi II, Nkam division, in the Littoral region of Cameroon. It is located between $4^{\circ} 06^{\prime}$ latitude North and $9^{\circ} 31^{\prime}$ longitude East. The population of Massoumboum is mainly composed of Bassa (80\%) and Bakoko (20\%) ethnic groups, spread in 441 inhabitants. The climate is humid, with rainfall ranging from 2900 to $3000 \mathrm{~mm}$; the temperature varies between $23^{\circ} \mathrm{C}$ and $29^{\circ} \mathrm{C}$, with February being the most warm month. Soils are lateritic, characterized by the presence of stons and termite mounds (Anonyme, 2011). The Lehman agroforest system of Massoumboum (ALM) is vast of 18.27 ha and is composed of many fruit plants including palm oil (Elaeis guineensis), goyava (Psidium guajava), Safou (Dacryodes edulis), and many citrus plants such as lemon (Citrus limon), orange tree $(C$. sinensis), grapefruit tree $(C$. grandis) and mandarin tree (C. reticulata).

The ALM is composed of three blocs including Campement, Ngock mpoo, and Papass.

The bloc Campement is composed of ananas (Ananas comosus), bananas (Musa paradisiaca and Musa sapientum), palm oil and goyava. The spontaneous vegetation is quite diversified and composed mostly of Chromolaena odorata, Musanga cecropioides and G. qfricanum. Its surface area is 7.09 hectares (ha).

The bloc Ngock mpoo is composed only of palm oil and goyava. The spontaneous vegetation is less abundant due to the clearing activities that occured between the months of January and March 2017. Its surface area is 6.66 ha.

In addition to the palm oil and goyava, the bloc Papass is composed of Citrus trees. The vegetation is well developed and diversified. This bloc has been less cleared. Its surface area is $4.52 \mathrm{ha}$.

People of Massoumboum village belong to the Bassa and Bassow ethnic groups. They use to harvest freely Gnetum africanum in the ALM.

\subsection{Biological Material}

The genus Gnetum belongs to the Gnetaceae family group. It has 30 species, composed mainly of lianas spread in Asia, America and Africa. Two species are found in Africa: Gnetum africanum Welw. and Gnetum buchholzianum (Mialoundama, 1993). The two lianas are dioecious, vines, ramified with nods. The stem can attend $10 \mathrm{~m}$ in length. Leaves are opposite, with a large limb, oval and elliptic. Fruits are small red cherries. The two species are not easily differentiated through their vegetative organs. In G. africanum, internode of male is spike of the same diameter throughout its length, slender in dried (or old) specimens. Staminal column exserted 
from the mouth of the envelope. Leaves ovate-oblong or elliptic-oblong, more rarely lanceolate, attenuate at base, abruptly acuminate, $10-13 \mathrm{~cm}$ long, and $3.5-5 \mathrm{~cm}$ broad. In contrary for $G$. buchholzianum, internode of male is spike in fresh condition much thicker at the base than higher up. Staminal column hardly exserted from the mouth of the envelope. Leaves ovate-elliptic or broadly elliptic, rounded or very slightly cuneate at base, abruptly acuminate, 9-14 cm long, 4-7 cm broad (Hutchinson and Dalziel, 1954, in Clark and Sunderland, 2004 cit. Ingram et al., 2012).

G. africanum tolerates for its development and growth, habitats of medium altitude, mostly the land ecosystems which range from fallows to primary forests, passing through secondary forests and forest galleries. In those habitats, G. africanum lianas appear as bushes climbing on trees or shrubs, or spread on soil. G. africanum is an evergreen plant, which can adapt even on the most difficult conditions. It uses reserves contained in its tuberized roots (Edissigue, 1991, Shiembo, 1999). This explains the survival of that plant specie during many years in degraded areas, even when the host plants have been destroyed. In tropical Africa, the distribution area of $G$. africanum ranges from Nigeria to Angola passing through Cameroon, the Central African Republic, Gabon, Congo, and Democratic Republic of Congo (Mialoundama, 1993).

In Cameroon, in addition to the forest that can be considered as its original ecological niche G. africanum can be found in fallows of Chromolaena odorata, long fallows of Musanga cecropioides, secondary forests, shrub savannas, farms of Elaeis guineensis. The specie is found in the South cameroonian plateau, at $700 \mathrm{~m}$ of altitude, in the dense semi-deciduous forest of Sterculiaceae and Ulmaceae, the low lands of the West region, the atlantic forest of Caesalpiniaceae, shrub savannas of Bridelia ferruginea at about $950 \mathrm{~m}$ of altitude. The plant seems to adapt to all forest habitats, except for the flooded forests of the Nyong valley and of the Littoral mangrove swamps (Letouzey, 1985a, b ; Edissigue, 1991; Ndoye et al., 1998).

\subsection{Method}

The method used in this work includes ethnobotanical inquiries and forest inventories.

\section{Ethbotanical surveys}

Ethnobotanical surveys were conducted among harvesters and sellers of G. africanum in Massoumboum and in two markets at the Douala city. In Massoumboum, we interviewed five women involved in the harvesting of $G$. africanum in the ALM. To each harvester we ask questions regarding the harvesting technic, the frequency of the harvesting, the quantity of the product harvested, at which period is done the harvesting, how the product is transported to the markets, at what cost, which markets, what are the financial revenues. In the markets, surveys were conducted in two phases including the rainy season (July-September 2017) and the dry season (November-December 2017). For each seller of Gnetum, we asked questions regarding the locality of procurement of the product, the frequency of selling, the quantity of the product sold par month, week, and we bougth some bundles (paquet) of leaves. For each bundle, we noted the price in CFA franc ( 1 euro $=650$ CFA franc), we weighted with a balance (mark YEN YEN 2010) having the sensitivity of 50 grammes and a threshold mass of 10 kilogrammes, we noted the mass, and we recorded the number of leaves contained in the bundle.

\section{Forest inventories}

The method used to assess the abundance and the potential of G. africanum in the ALM is the one call "method for forest management inventories". This method consists of counting the number of stems of the resource on a representative sampling area and to estimate the stock at the level of the useful forest area. The inventory of $G$. africanum in the ALM was conducted from $5^{\text {th }}$ September to $23^{\text {rd }}$ October 2017. The ALM is vast of 18.27 ha for a useful area (this is the area where the presence of G. africanum is evident) of 12.6 ha. Twelve (12) lines of 100 $\mathrm{m}$ long each were settled on the total area of the ALM. This gives a total of four lines per bloc, distant each other of $100 \mathrm{~m}$. In each line, we delimitated 10 continuous plots of $100 \mathrm{~m}^{2}(10 \mathrm{~m} \times 10 \mathrm{~m})$, rotating left and right. This gives a sampling area of 1.2 ha and a sampling rate of $9.52 \%$ compared to the useful area and $6.57 \%$ compared to the total area. In each plot, all stems of G. africanum were identified and counted. For each stem, we recorded its diameter in the collar using the calliper rule, we recorded the number of leaves and we measured the length.

Data recorded were introduced in Excel 2013 and following quantitative values were calculated:

- Density ( $\mathrm{Di})=\mathrm{Ni} / \mathrm{Ss}$ with Ni being the number of stems (or leaves) and Ss being the sampling area (in ha) ; this express the number of individuals or leaves per ha ;

- The potential or stand stock $(\mathrm{P})=\mathrm{Di} x \mathrm{Su}$ with Di being the density and Su being the useful area (in ha). The stand stock express the quantity of the resource (individuals or stems) or products (leaves) in the whole area, the plantation in this case.

Data analysis 
Data analysis was performed using the R version 3.5.1 (2018-07-02), Ri 386 computer packages. This bundleage served to make the one way ANOVA and to search correlations. The one way ANOVA was used for example to assess the variance in the price of the product in different markets, procurement areas, and seasons. The method used to explore the correlation between the length of stems and the density is that of Pearson.

\section{Results}

\subsection{Harvesting and Trade of Gnetum africanum}

\section{Socio-economic profile of harvesters}

A total of five women harvesters, belonging to the Bassa ethnic group were met and interviewed. They all use to harvest freely G. africanum in the ALM. Their age varies between 24 and 56 years old. The five women can be distinguished in two groups including Youngers and elders. The first group or Youngers are two single girls, 24 and 30 years old respectively. They are specialized in the harvesting and selling of G. africanum. The second group (60\%) is composed of three elders 45,48 and 56 years old who are working not only on the harvesting and trade of G. africanum, but also involved in many other activities and mostly agriculture.

\section{Harvesting activities}

The harvesting of G. africanum begins early in the morning, without rain. The time spent per day for harvesting can be 6-8 hours, depending to the topography of the field. The prospection of Gnetum can take 2 or 3 days. The harvesting method consists of cutting the stems at $10 \mathrm{~cm}$ above the ground (the method which is largely used) or harvesting leaf after leaf from stems.

\section{Trade circuits}

Two trade circuits can be observed from the ALM to the final markets in the city of Douala. The first circuit goes from the forest to the stocking area. The product is transported by the harvester herself. The second circuit goes from the stocking area to the markets, and is transported by the bikes or taxis. The bikes transport the products from the stocking area to the $\mathrm{Pk} 14$ or 21 markets, while taxis transport those products from the Pk markets to the city markets. The price of the transport by bike is 1000 CFA franc ( 1 euros $=650$ CFA franc) for a bag of 50 $\mathrm{kg}$ and $1500 \mathrm{CFA}$ franc for a bag of $100 \mathrm{~kg}$. For taxis, the harvester has to pay additional price of $500 \mathrm{CFA}$ franc whatever be the quantity, to reach the market of Ndokotti syncatex at Douala city.

Selling of G. africanum in the markets

A total of 130 bundles of leaves of G. africanum were recorded and bought from four sellers settled in four markets including : New bell and Ndokoti syncatex in the Douala city, and Pk 14 and Pouma located respectively at 14 kilometers and $80 \mathrm{~km}$ to Douala city. The distribution of bundles in different seasons is as follow: 100 bundles in the rainy season and 30 bundles in the dry season (table 1). Ndokotti syncatex is the market which gets the high number of bundles, 80. Bundles of Gnetum found in the markets come from three main areas including Boum-nyebel, Massoumboum and surrounding villages, and Song Pagal. The high quantity of the product (74\%) comes from the Boum-nyébel market, based at about $130 \mathrm{~km}$ from Douala. Boum-nyebel feeds two markets of Douala city: New-Bell and Ndokotti syncatex.

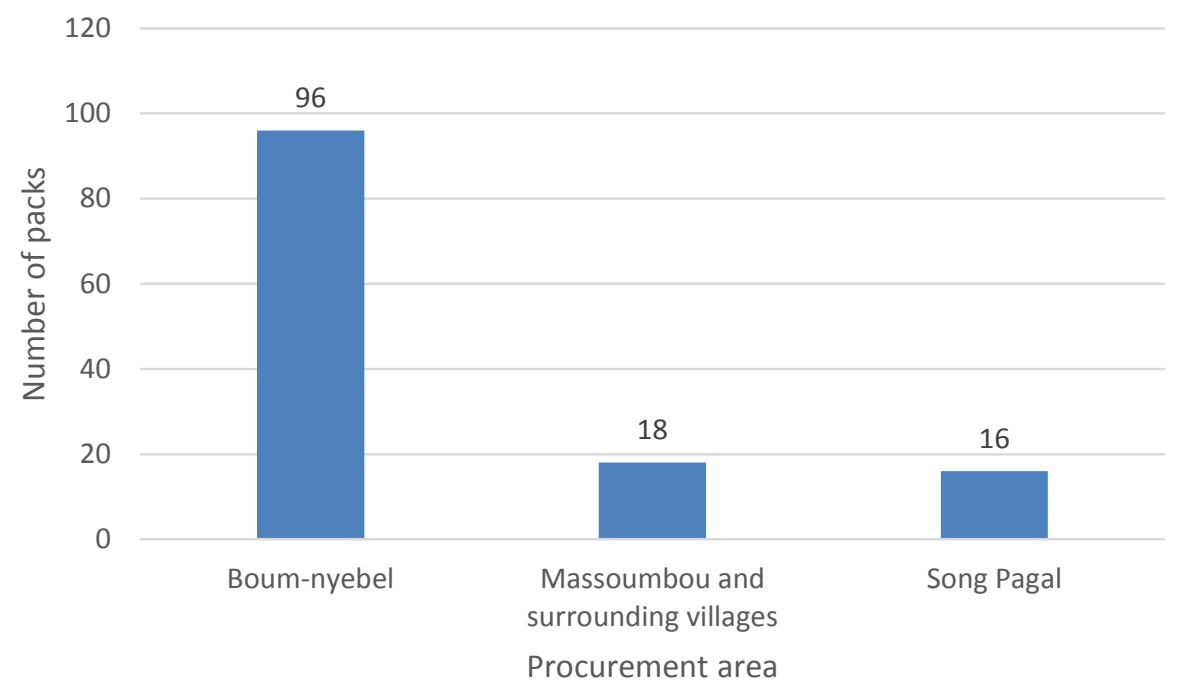

Figure 1. Procurement areas of Gnetum africanum in markets 
Table 1. Distribution of bundles of G. africanum weigth and bougth in different markets and seasons in Douala and surrounding cities

\begin{tabular}{lllll}
\hline Procurement area & Market & $\begin{array}{l}\text { Code of } \\
\text { the seller }\end{array}$ & $\begin{array}{l}\text { Number of } \\
\text { bundles per season }\end{array}$ \\
\hline & & & Rainy season & Dry season \\
Boum-nyebel & Ndokotti syncatex (Douala) & Sel1 & 50 & 30 \\
& New-bell (Douala) & Sel2 & 16 & \\
Massoumboum and surrounding villages & Pk14 (14 km to Douala) & Sel3 & 18 & \\
Song Pagal (Pouma) & Pouma (80 km to Douala) & Sel4 & 16 & \\
Total & $\mathbf{4}$ & $\mathbf{4}$ & $\mathbf{1 0 0}$ & $\mathbf{3 0}$ \\
\hline
\end{tabular}

The average price of the gramme is 0.58 CFA franc \pm 0.15 . This price varies significantly from one market to another as presented in table $2(\mathrm{P}<0.001)$. Pk14 and Pouma markets have the highest price of the gramme. The average price of the gramme in the two markets of Douala is 0.51 CFA franc while the average price of the gramme in the periphery of Douala is 0.7 CFA franc. Table 3 compares the average price of gramme of $G$. africanum in different procurement areas. This price varies significantly from one procurement area to another $(\mathrm{P}<0.001)$. G. africanum coming from Massoumboum and surrounding villages is the most expensive $0.71 \pm 0.18$ CFA franc while that coming from the Boum-nyébel market has the cheapest price. The comparison of the price of the gramme between the two seasons is done in table 4 . The price of the gramme differs significantly from one season to another $(\mathrm{P}<0.001)$. The highest price of the gramme being observed during the dry season, $0.69 \pm 0.09$ CFA franc. The second comparison of the price of the gramme in different seasons was limit to the same sellers surveyed in the Ndokotti syncatex market at Douala (table 5). The price of the gramme of $G$. africanum differs significantly for the same sellers between the two seasons $(\mathrm{P}<0.001)$. The price of the gramme in the dry season is high 1.4 time that observed in the rainy season.

Table 6 presents the comparison between the number of stems per bundle among different markets. The number of stems per bundle does not really vary from one market to another $(\mathrm{P}>0.05)$. The average number of stems per bundle is $580 \pm 139.7$. Pk 14, which hosts G. africanum coming from ALM has the lowest number of stems per bundle, 519. The number of leaves was counted in the 30 bundles bougth during the dry season, in the Ndokotti syncatex market and the correspondance price was calculated (table 7). One bundle of Gnetum contains an average number of 2695 leaves and costs 800 CFA franc. Each leaf can cost $0.31 \pm 0.05$ CFA franc in Ndokotti syncatex market.

Table 2. Comparison of the price of the gramme of G. africanum in different markets surveyed in Douala and surrounding cities

\begin{tabular}{lccccc}
\hline Market & Mean & $\mathrm{Sd}$ & $\mathrm{n}$ & $\mathrm{F}$ value $=13.53$ & $\operatorname{Pr}<0.000000104 * * *$ \\
\hline Ndokotti syncatex & 0.56 & 0.13 & 80 & & \\
New-bell & 0.47 & 0.10 & 16 & & \\
Pk 14 & 0.71 & 0.18 & 18 & & \\
Pouma & 0.69 & 0.08 & 16 & & \\
All markets & 0.58 & 0.15 & 130 & &
\end{tabular}

The F value and Pr are from the comparison between different markets. Signif. codes: 0 '***' $0.001^{\prime} * *{ }^{\prime} 0.01^{\prime} *{ }^{\prime}$ 0.05 '.' $0.1^{\prime \prime} 1$

Table 3. Comparison of the price of the gramme of G. africanum in different procurement areas

\begin{tabular}{lccccc}
\hline Procurement area & Mean & $\mathrm{Sd}$ & $\mathrm{n}$ & $\mathrm{F}$ value $=16.58$ & $\operatorname{Pr}<0.000000399 * * *$ \\
\hline Boum-nyébel market & 0.54 & 0.13 & 96 & & \\
Massoumboum and surounding villages & 0.71 & 0.18 & 18 & & \\
Song-pagal Village (Pouma) & 0.69 & 0.08 & 16 & & \\
\hline
\end{tabular}

The $\mathrm{F}$ value and $\mathrm{Pr}$ are from the comparison between different procurement areas. Signif. codes: $0{ }^{\prime * * * ' 0.001}$ '**' 0.01 '*' 0.05 '.' 0.1 ' ' 1 
Table 4. Comparison of the price of the gramme of G. africanum in different seasons

\begin{tabular}{lccccc}
\hline Season & Mean & $\mathrm{Sd}$ & $\mathrm{n}$ & $\mathrm{F}$ value $=21.9$ & $\operatorname{Pr}<0.0000072 * * *$ \\
\hline Dry season & 0.69 & 0.09 & 30 & & \\
Rainy season & 0.55 & 0.15 & 100 & & \\
\hline
\end{tabular}

The $\mathrm{F}$ value and $\mathrm{Pr}$ are from the comparison between different seasons. Signif. codes: $0{ }^{\prime * * * \prime} 0.001^{\prime * * \prime} 0.01^{\prime *}{ }^{\prime}$ 0.05 '.' $0.1^{\prime \prime} 1$

Table 5. Comparison of the price of the gramme of G. africanum in different seasons among the same sellers

\begin{tabular}{lccccc}
\hline Season & Mean & $\mathrm{Sd}$ & $\mathrm{n}$ & $\mathrm{F}$ value $=106.6$ & $\operatorname{Pr}<3.01 \mathrm{e}-16 * * *$ \\
\hline Dry season & 0.69 & 0.09 & 30 & & \\
Rainy season & 0.48 & 0.08 & 50 & & \\
\hline
\end{tabular}

The F value and Pr are from the comparison between different seasons. Signif. codes: 0 '***' $0.001^{\prime} * *{ }^{\prime} 0.01^{\prime *}$ 0.05 '.' 0.1 ' ' 1

Table 6. Comparison of the number of stems of G. africanum per bundle in different markets

\begin{tabular}{llllll}
\hline Market & Mean & Sd & $\mathrm{n}$ & $\mathrm{F}$ value $=1.986$ & $\operatorname{Pr}<0.119$ \\
\hline Ndokotti syncatex & 588.9 & 136.6 & 80 & & \\
New-bell & 557.0 & 164.2 & 16 & & \\
Pk 14 & 519.1 & 140.7 & 18 & & \\
Pouma & 624.8 & 624.9 & 16 & & \\
All markets & 579.7 & 139.7 & 130 & & \\
\hline
\end{tabular}

The F value and Pr are from the comparison between different markets. Signif. codes: 0 '***' 0.001

Table 7. Number of leaves of G. africanum per bundle

\begin{tabular}{llll}
\hline Parameter & Mean & $\mathrm{Sd}$ & $\mathrm{n}$ \\
\hline Price of the bundle in all markets & 627.70 & 149.42 & 130 \\
Number of leaves per bundle & 2695.33 & 503.14 & 30 \\
Price of the bundle in dry season at Ndokotti syncatex & 800 & & 30 \\
Price of the leaf in dry season at Ndokotti syncatex & 0.31 & 0.05 & 30 \\
\hline
\end{tabular}

Table 8. Characteristics of the inventory of Gnetum africanum realized in the ALM

\begin{tabular}{llll}
\hline Bloc & Surface area (ha) & Sampling area (ha) & Sampling rate (\%) \\
\hline Campement & 7.09 & 0.4 & 5.6 \\
Ngock mpoo & 4.52 & 0.4 & 8.8 \\
Papass & 6.662 & 0.4 & 6 \\
Total & 18.27 & 1.2 & 6.6 \\
\hline
\end{tabular}

\subsection{Density and Stand Structure of G. africanum in the ALM}

\section{Characteristics of the sampling/inventory}

The global sampling rate is $6.6 \%$. Ngock mpoo is the bloc which was highly sampled (8.8\%).

Density of G. africanum in the ALM

Globally, G. africanum appears as bushes, with voluble stems found on soils or which surround different trees and shrubs including Chromolaena odorata, Elaeis guineensis, Dacryodes edulis, Psidium guajava, Citrus spp.

Table 9 presents the density of G. africanum per bloc in term of number of stems and leaves. A total of 7429 stems and 143457 leaves of G. africanum were counted on the 102 plots delimitated (1.2 ha), which gives a density of 6190 stems/ha and 119547.5 leaves/ha (table 9). The bloc Campement has the highest density of stems (6 525 stems/ha) while Papass has the highest density of leaves (167 705 leaves/ha). 
Table 9. Density of stems and leaves of G. africanum per bloc in the ALM

\begin{tabular}{llllll}
\hline Nom du bloc & $\begin{array}{l}\text { Sampling } \\
\text { area (ha) }\end{array}$ & $\begin{array}{l}\text { Number } \\
\text { of stems }\end{array}$ & $\begin{array}{l}\text { Number } \\
\text { of leaves }\end{array}$ & $\begin{array}{l}\text { Density } \\
\text { of stems }\end{array}$ & $\begin{array}{l}\text { Density } \\
\text { of leaves }\end{array}$ \\
\hline Campement & 0.4 & 2610 & 40038 & 6525 & 100095 \\
Ngock mpoo & 0.4 & 2405 & 36337 & 6012 & 90842.5 \\
Papass & 0.4 & 2414 & 67082 & 6035 & 167705 \\
Mean/total & 1.2 & 7429 & 143457 & 6190 & 119547.5 \\
\hline
\end{tabular}

Stand structure in length of G. africanum

Lengths of G. africanum stems inventoried were distinguished in class of $10 \mathrm{~cm}$ (table 10). Papas is the bloc which has many stems long than $400 \mathrm{~cm}$. A total of 22 stems in Papass are long than $400 \mathrm{~cm}$ compared to 7 for the bloc Campement and 1 for the bloc Ngock mpoo. The curve showing the distribution of stems of $G$. africanum in length classes is illustrated in figure 2 . The figure shows a reverse $\mathbf{J}$ shape curve which illustrates a good regeneration. The modal class is $3(30 \mathrm{~cm})$. Table 11 presents the average lengths of stems in different blocs. The average length of stems is $60.1 \mathrm{~cm}$. There are significance differences between the lengths of stems in different blocs $(\mathrm{P}<0.001)$. Papass is the bloc which hosts the high mean of the length, $87.5 \mathrm{~cm}$.

Tableau 10. Distribution stems of G. africanum in different classes of length or high in blocs. $1: 10 \mathrm{~cm}, 2: 20 \mathrm{~cm}$, $3: 30 \mathrm{~cm}$, $40: 400 \mathrm{~cm}$

\begin{tabular}{|c|c|c|c|c|}
\hline Class of length & Campement & Ngock mpoo & Papass & Total \\
\hline 1 & 37 & 24 & 17 & 78 \\
\hline 2 & 603 & 449 & 272 & 1324 \\
\hline 3 & 695 & 688 & 464 & 1847 \\
\hline 4 & 294 & 254 & 227 & 775 \\
\hline 5 & 213 & 194 & 123 & 530 \\
\hline 6 & 162 & 150 & 102 & 414 \\
\hline 7 & 143 & 122 & 126 & 391 \\
\hline 8 & 103 & 78 & 61 & 242 \\
\hline 9 & 71 & 82 & 91 & 244 \\
\hline 10 & 45 & 50 & 65 & 160 \\
\hline 11 & 70 & 78 & 100 & 248 \\
\hline 12 & 35 & 41 & 95 & 171 \\
\hline 13 & 20 & 32 & 75 & 127 \\
\hline 14 & 13 & 21 & 29 & 63 \\
\hline 15 & 8 & 14 & 34 & 56 \\
\hline 16 & 45 & 26 & 123 & 194 \\
\hline 17 & 4 & 22 & 46 & 72 \\
\hline 18 & 1 & 7 & 24 & 32 \\
\hline 19 & 4 & 14 & 39 & 57 \\
\hline 20 & 1 & 5 & 11 & 17 \\
\hline 21 & 17 & 21 & 84 & 122 \\
\hline 22 & 2 & 6 & 33 & 41 \\
\hline 23 & 4 & 1 & 17 & 22 \\
\hline 24 & & & 9 & 9 \\
\hline 25 & 1 & 3 & 11 & 15 \\
\hline 26 & 3 & 4 & 40 & 47 \\
\hline 27 & 1 & 2 & 14 & 17 \\
\hline 28 & & & 1 & 1 \\
\hline 29 & 1 & 8 & 10 & 19 \\
\hline 30 & & 1 & 1 & 2 \\
\hline 31 & 4 & 4 & 24 & 32 \\
\hline 32 & & & 5 & 5 \\
\hline 33 & & 1 & 4 & 5 \\
\hline 34 & 1 & & & 1 \\
\hline 35 & 2 & 1 & 3 & 6 \\
\hline
\end{tabular}




\begin{tabular}{lllll}
\hline Class of length & Campement & Ngock mpoo & Papass & Total \\
\hline 36 & & & 7 & 7 \\
38 & & 1 & 1 & 2 \\
39 & & & 4 & 4 \\
41 & 6 & & 10 & 16 \\
42 & 1 & & 2 & 3 \\
43 & & 1 & 1 \\
45 & & 1 & 1 \\
46 & & & 3 & 4 \\
47 & & & 2 & 2 \\
51 & & 3 & 3 \\
Total général & $\mathbf{2 6 1 0}$ & $\mathbf{2 4 0 5}$ & $\mathbf{2 4 1 4}$ & $\mathbf{7 4 2 9}$ \\
\hline
\end{tabular}

Table 11. Average length/high of stems of G. africanum in ALM

\begin{tabular}{lllll}
\hline Bloc & Average length $(\mathrm{cm})$ & $\mathrm{n}$ & F value $=382.9$ & $\operatorname{Pr}<2 \mathrm{e}-16 * * *$ \\
\hline Campement & 44.4 & 2610 & & \\
Ngock mpoo & 49.8 & 2405 & & \\
Papass & 87.5 & 2414 & & \\
Total/mean & 60.1 & 7429 & & \\
\hline
\end{tabular}

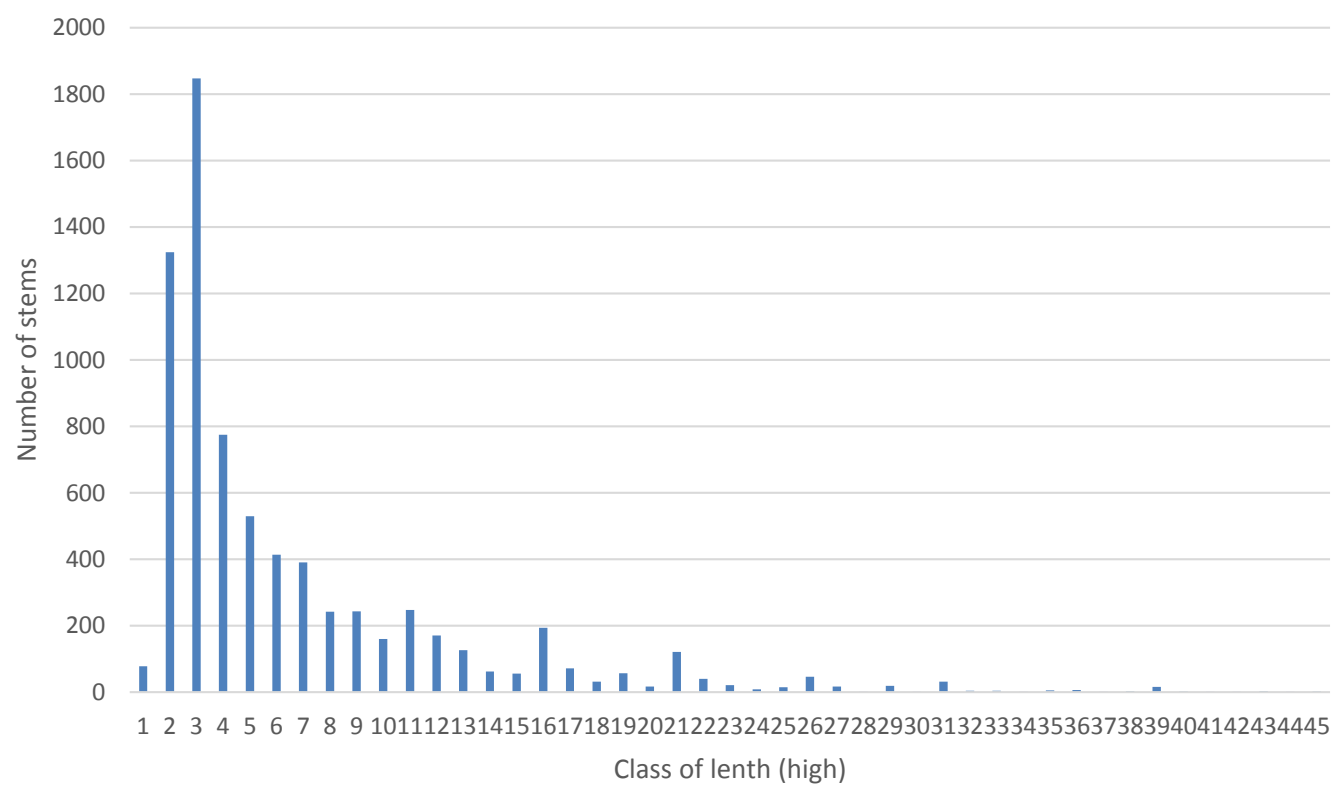

Figure 2. Length structure of stems of G. africanum in the ALM

Relation between the length of the stems and the density of G. africanum

The matrix of the relation between the length of stems and the density of G. africanum is presented in table 12 . The method used for the correlation is that of Pearson. We can see that the length of the stem is positively correlated to the density of leaves and negatively correlated to the density of stems.

Table 12. Correlation between the length of stems and the densities of G. africanum in the ALM (Pearson method)

\begin{tabular}{llll}
\hline & Density of leaves & Density of stems & Length of stems \\
\hline Density of leaves & 1 & -0.36 & 0.97 \\
Density of stems & -0.364 & 1 & -0.56 \\
Length of stems & 0.97 & -0.56 & 1 \\
\hline
\end{tabular}




\section{Temporal potential of the ALM in G. africanum}

The temporal potential which represents the product of the density and the surface area is shown in table 13 . The potential of the ALM in G. africanum is estimated at 113106 stems and 2184133 leaves. The high potential of leaves is observed in Bloc Papass with 1117251 leaves, which represents 51\% of the total.

Table 13. Temporal potential of G. africanum in the ALM

\begin{tabular}{llllll}
\hline Bloc & $\begin{array}{l}\text { Total area } \\
\text { (ha) }\end{array}$ & $\begin{array}{l}\text { Density of } \\
\text { stems (stems/ha) }\end{array}$ & $\begin{array}{l}\text { Density of } \\
\text { leaves (leaves/ha) }\end{array}$ & $\begin{array}{l}\text { Potential } \\
\text { of stems }\end{array}$ & $\begin{array}{l}\text { Potential } \\
\text { of leaves }\end{array}$ \\
\hline Campement & 7.1 & 6525.0 & 100095.0 & 46262.3 & 709673.6 \\
Ngock mpoo & 4.5 & 6012.0 & 90842.5 & 27174.2 & 410608.1 \\
Papass & 6.7 & 6035.0 & 167705.0 & 40205.2 & 1117250.7 \\
Total/moyenne & 18.3 & 6190.8 & 119547.5 & 113105.9 & 2184132.8 \\
\hline
\end{tabular}

\subsection{Temporal Economic Value of the ALM in G. africanum}

The Economic value (Ev) of the ALM in G. africanum is evaluated here in terms of leaves and bundles (table 14). The temporal Ev of the ALM in G. africanum can range from 500000 CFA franc to 700000 CFA franc. Knowing that the average price of a leaf is 0.31 CFA franc, the economic value of the ALM in G. africanum can be estimated at $37059.9 \mathrm{FCFA} / \mathrm{ha}$.

Table 14. Economic value of the ALM in G. africanum

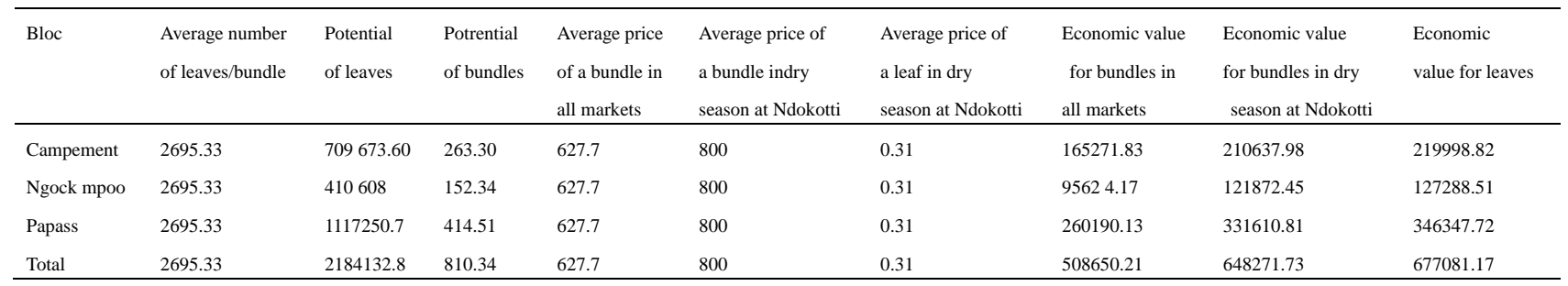

\section{Discussion}

\subsection{Harvesting and Trade of G. africaum}

Harvesters of G. africanum of the ALM are essentially composed of women, single and married, youngers (40\%) and elders $(60 \%)$. The youngers are specialized in harvesting and trade of $G$. africanum while the elders practise other activities such as agriculture. The two groups use two technics for havesting the plant : cutting stems or harvesting leaf after leaf. Same observations were made by Awono et al. (2002) and Nlend (2007) in Monatele and Sa'a, Lékié division, Centre region of Cameroon. In the South West region of Cameroon, retailers were all found to be women, largely local, married. They specialize in Gnetum leaves although $31 \%$ have parallel trade in other products, mainly agricultural activities (Ingram et al., 2012). Cameroonian woman is in the Centre of harvesting and trade of NTFP in general and of G. africanum in particular. Trade of G. africanum allows to resolve financial problems of the family (Awono et al., 2002). In contrary, in the Democratic Republic of Congo (DRC), the harvesting and trade of G. africanum (Fumbwa) is done by men. Two reasons explain this situation : the harvesting method consists of felling host trees and the economic profit is high compared to other activities (Manirakiza et al., 2009). In Massoumboum, trade circuit of $G$. africanum include two steps done by the harvester herself : from the forest to the storing area in the village, and from the village to the markets using taxis and bikes. In the Centre region, trade of G. africanum includes several steps and stakeholders : harvester, storage, wholesaler, seller, leaf-cutter (Mbolo, 2002). In the South-west region, trade of G. africanum also involves many stakeholders and steps (Ingram et al., 2012). In Massoumboum, the harvesting of Gnetum begins early in the morning, without rain. The time spent per day for harvesting can be 6-8 hours, depending to the topography of the field. In the South-west region, the harvesting time varies from 40 minutes to 9 hours, when harvesters leave in the early morning and return around $4 \mathrm{pm}$, spending on average 3-4 hrs travelling (Ndumbe et al., 2009).

The price of the gramme of a bundle of G. africanum varies from one market to another, from one procurement area to another and from one season to another. The price of the gramme is high in markets located in the periphery of Douala city (0.7 CFA franc/gramme) compared to the price practised in the Douala city markets (0.51 FCFA). This situation can be explained by the fact that Douala is a big city, which receives products comming from different areas compared to the periphery or rural areas. Also, the rural areas and mostly Pk and 
Pouma (the littoral region) are not considered to be in the original ecological niche of G. africanum. The price of the gramme obtained in different markets in Cameroon are as follow : 2 CFA franc (Betti et al., 2016) and 0.6 CFA franc (Mbolo, 2002) in Yaounde, 0.45 CFA franc in Boum-nyebel, 0.7 CFA franc in Limbe, and 0.15 CFA franc in the periphery of Yaoundé (Mbolo et al., 2012). In the South west region, the average price per gramme is 0.82 CFA franc while that obtained in Nigeria (Calabar and Ikang) average 1.5 CFA franc (Ingram et al., 2012). The low price of the gramme observed in the periphery of the Yaounde city, in the division of Lekie and Mbam to be precised, may be due to the fact that the Centre region is located in the original ecological niche of $G$. africanum in Cameroon, compared to the littoral region where we have many swamp forests and swamp mangroves known as non-suitable habitats for G. africanum development and growth (Edissigue, 1991; Ndoye et aI., 1998). The price of the gramme is high in dry season compared to the rainy season. This can be explained by the scarcity of other products including agricultural products or vegetables such as cassava leaves and other NTFP during the dry season (Ingram et al., 2012).

\subsection{Density and Stand Structure of G. africanum in the ALM}

The sampling rate obtained in our inventory is $6.5 \%$, which is in comformity with the norms of forest management inventories proposed by the forest administration in Cameroon. According to those norms, the sampling rate to apply for surface areas less or equal to 5000 ha should be at least equal to $2 \%$. The average density of G. africanum in the ALM is 6191 stems/ha and 119548 leaves/ha. The density of stems is less compared to the 46945 stems/ha obtained in the Lekié division, Centre region of Cameroon by Mbolo (2002). This difference between the two densities of stems can be explained by two reasons. The first is related to the location of the Lekié division in the original ecological niche of G. africanum ; and the second reason is related to the degree of perturbation of the habitat. Our inventory was conducted in a plantation, which is regularly cleared, while the work of Mbolo (2002) was conducted in fallows and secondary forests. The density of leaves is link to the length of the stems, which explains the high density of leaves obtained in the bloc of Papass compared to the bloc Ngock mpoo. In fact, the bloc Ngock mpoo has been cleared some months before the inventory, while Papass has been not cleared since long time. Stems in Papass had enough time to grow and reach high lengths. The specific structure of G. africanum in terms of the length of stems reveals a reversed $\mathbf{J}$ shape curve, illustrating a good regeneration of the plant. This means that, the plant may not be treathenned in the ALM, since old stems will be easily replaced by the youngers. The only problem to solve resides on the application of the fair fresqency and the technics of harvesting. This remains the challenge of the work to be done.

\subsection{Economic Value, Potential and Sustainaibility of G. africanum in the ALM}

The potential of the ALM is estimated at 113106 stems and 2184133 leaves. The economic value estimated for the ALM in G. africanum can range from 500000 - 700000 CFA franc. Knowing that the average price of a leaf is $0.31 \mathrm{CFA}$ franc, the economic value of the ALM in G. africanum can be estimated at $37059.9 \mathrm{CFA}$ franc/ha. If well managed, G. africanum can contribute not only to the economy of the women-harvesters, but also to the economy of the ALM. In the Massoumboum, harvesters have obtained the authorization of the owner of the ALM before entering in the plantation. The growing development challenge to be done is the settlement of tools for sustaining the resource and trade. These are tools which aim to make sure the trade of the product is non-detrimental to the survival of the resource in the forest, known in other word as «non-detriment findings » (NDF). In spite of its important economic value, the trade of G. africanum is not yet well regulated in Cameroon (Betti, 2007 ; Ingram et al., 2012). This trade is, in theory, regulated under the 1994 Forest, Wildlife and Fisheries Law (No 94/01). According to the forest law, all forests belong to the Cameroonian State and adjacent communities have user rights for own (not commercial) use of forest resources. But many people however, are unaware of this and/or believe that forests belong to them and can be freely exploited for commercial use (Laird et al., 2010). In 1995, the trade led to G. africanum being declared as an endangered species and a ban considered (but never implemented) in 1999 (Fondoun and Tiki Manga cit Ingram et al., 2012). Cameroon government has made many efforts to improve the exploitation and trade of forest products, compared to other many african countries. But many problems still remain in the field of NTFP or specialized products (Betti, 2007 ; Betti et al., 2016 ; Ingram et al., 2012). The quota of harvesting G. africanum as many other specialized products is not based on fair forest inventories (Betti, 2007). It would be interesting if Cameroon authorities extends the work conducted on Prunus africana, another special product (Betti et al., 2011) of huge interest to other products in general and to G. africanum in particular. This includes: the identification of the high production sites, the delimitation of the sites in Gnetum Allocation Units (GAU), the realization of forest inventories, the development of simple management plans (SMPs), and the implementation of those SMPs. 


\section{Conclusion}

This study aimed to characterize the harvesting and trade of G. africanaum, and to assess its abundance (density and structure) in order to appreciate the economic value of the Lehman agroforest system at Massoumboum (ALM), Littoral region of the study reveals that the harvesting of G. africanum is freely done by women. The inventories conducted revealed densities of 6191 stems/ha and 119548 leaves/ha. The combination of field data (forest inventories) with those obtained in the markets (trade data) allowed to appreciate the temporal economic value (EV) of the AKM. If well managed, G. africanum can contribute not only to the economy of the women-harvesters, but also to the economy of the ALM. The growing development challenge of the background of what is discuss in this paper is the development of non-detriment findings (NDF) for G. africanum in Cameroon. These consist of setting tools which aims to sustain the resource and trade.

\section{Acknowledgement}

We thank all people who accept to respond to our questions. The study was conducted with the logistical assistance of Pr Leopold LEHMAN, the owner of the ALM.

\section{References}

Anonyme (2011). Monographie départementale du Nkam. Ligneux dans le cadre du Central African Regional Programme for the Environment (CARPE), Forestry Support Program, USAID, Washington, USA.

Awono, A., Ngono, D. L., Ndoye, O., Tieguhong, C. J., Eyebe, A., \& Mahop, M. T. (2002). Etude sur la Commercialisation de Quatre Produits Forestiers Non-Ligneux dans la Zone Forestiere du Cameroun: Gnetum spp., Ricinodendron heudelotii, Irvingia spp., Prunus africana. FAO, Yaounde'.

Awono, A., Eba'a, A. R., Betti, J. L., Ngouhouo, P. J., Foundjem, T. D., \& Tieguhong, C. J. (2013). Importance économique et sociale des produits forestiers non ligneux de nature végétale au Cameroun. In Etude de l'Importance Economique et Sociale du Secteur Forestier et Faunique au Cameroun. Ministère des Forêts et de la Faune-CIFOR: Yaonudé, 129-130.

Betti, J. L. (2007). Plan d'action/stratégie pour une meilleure collecte des données statistiques sur les Produits forestiers non ligneux au Cameroun et recommandations pour les pays de la COMIFAC. Projet Renforcement de la sécurité alimentaire en Afrique centrale à travers la gestion et l'utilisation durable des produits forestiers non ligneux, GCP/RAF/398/GER, FAO- COMIFAC - GTZ. P.180.

Betti, J. L., Belinga, S. J., \& Samba, D. (2011). Stock of Prunus africana stems on mount Cameroon. African Journal of Plant Sciences, 5(13), 781-789. https://doi.org/10.5897/AJPS11.195

Betti, J. L., Ngankoue, M. C., Njimbam, N. F. O., \& Wete, E. (2016). Monitoring the implementation of Prunus africana (Rosaceae) management plans in Cameroon: respect of norms. African Journal of Plants Sciences, 10(9), 172-188.

Edissigue, H. J. (1991). Etude monographique de Gnetum africanum (Gnetaceae). Mémoire de maîtrise. Université de Yaoundé. pp. 80.

FAO (2002). Non-wood forest products in Africa: A regional and national overview. Les produits forestiers non ligneux en Afrique: un aperçu régional et national. Par S. Walter. Document de travail FOPW/01/1. Rome. Retrieved from http:// www. fao.org /DOCREP/003/Y1515b00.HTM

Laird, S., Ingram, V., Awono, A., Ndoye, O., Sunderland, T., Lisinge, E., \& Nkuinkeu, R. (2010). Integrating customary and statutory systems: the struggle to develop a legal and policy framework for NTFPs in Cameroon. In: S. A. Laird, R. McLain \& R. P. Wynberg (Eds.), Wild product governance: finding policies that work for non-timber forest products. Earthscan, London. https://doi.org/10.4324/9781849775199

Letouzey, R. (1985 a et b). Notice de la carte phytogéographique du Cameroun au 1/500 000. IRA-Yde/ICIV. Toulouse. pp. 63-94, 95-142.

Manirakiza, D., Awono, A., Owona, H., \& Ingram, V. (2009). Mobilisation et renforcement des capacités des petites et moyennes entreprises impliquées dans les filières des produits forestiers non ligneux en Afrique Centrale. Etude de base de la filière fumbwa (Gnetum spp.) en RDC.GCP/RAF408/EC,CIFOR. pp. 79.

Mbolo, M. (2002). La collecte et l'analyse des données statistiques sur les produits forestiers non ligneux: une étude pilote au Cameroun. Programme de partenariat CE - FAO, Projet Collecte et analyse de données pour l'aménagement durable des forêts : joindre les efforts nationaux et internationaux, GCP/INT/679/EC, pp. 136.

Mialoundama, F. (1993). Nutritional and socio-economic value of Gnetum leaves in Central African forest. In: C. 
M. Hladik, A. Hladik, \& O. F. Linares, (Eds.), Tropical forests, people and food. Man and the biosphere series volume 13 (pp. 177-181). Parthenon Publishing Group, Carnforth, United Kingdom.

Ndoye, O., Ruiz, P. M., \& Eyebe, A. (1998). The markets of non-timber forest products in the humid forest zone of Cameroon. Rural Development Forestry Network (Network Paper 22c), 25

Ndumbe, L., Ingram, V., \& Awono, A. (2009) Eru market chain baseline (Gnetum spp.) in the Southwest and Littoral regions, Cameroon. Projet «Mobilisation et renforcement des capacités des petites et moyennes entreprises impliquées dans les filières des produits forestiers non ligneux en Afrique Centrale». GCP/RAF/408/EC, CIFOR report, pp. 141.

Nlend, V. G. B. (2007). L'exploitation de l'Okok (Gnetum africanum) par les femmes au Caméroun: analyse sociologique de l'émergence d'une cueillette de rente et de ses implications socioéconomiques et environnementales dans la région forestière de Sa'A. Faculté des lettres et sciences humaines. Institut de sociologie., Université de Neuchâtel. Mémoire de diplôme universitaire.

Shiembo, P. N. (1999). The Sustainability of eru (Gnetum africanum and Gnetum buchholzianum): an overexploited non-wood forest product from the forests of Central Africa. In: T. C. Sunderland, L. E. Clark, \& $\mathrm{P}$, Vantomme (Eds.), Non-Wood Forest Products in Central Africa; Current research issues and prospects for conservation development (pp. 61-66), FAO, Rome.

Tabuna, H. (1999). Evaluation des échanges des produits forestiers non ligneux entre l'Afrique subsaharienne et l'Europe. Rome: FAO, pp. 91.

Toirambe, B. B. (2002). Utilisation des feuilles de Gnetum sp. dans la lutte contre l'insécurité alimentaire et la pauvreté des pays de l'Afrique Centrale, cas de la République Démocratique du Congo. FAO. Rome (Italie). pp. 35 .

\section{Copyrights}

Copyright for this article is retained by the author(s), with first publication rights granted to the journal.

This is an open-access article distributed under the terms and conditions of the Creative Commons Attribution license (http://creativecommons.org/licenses/by/4.0/). 